\title{
Foreign aid and judicial autonomy
}

\author{
Margaret Ariotti ${ }^{1} \cdot$ Simone Dietrich $^{2}$ (1) $\cdot$ Joseph Wright ${ }^{3}$
}

Accepted: 7 June 2021 / Published online: 3 September 2021

(C) The Author(s) 2021

\begin{abstract}
Foreign aid donors increasingly embrace judicial autonomy as an important component of advancing democracy and promoting investment abroad. Recipient governments also recognize the importance of judicial reform for improving the investment climate at home. However, developing countries often lack the necessary state capacity that would enable them to implement these reforms. We argue that recipient countries that lack the state capacity to undertake reforms on their own turn to donors, who readily assist in judicial reforms via targeted democracy and governance interventions. At the same time, we suggest that the external assistance matters less for recipients that are able to implement judicial reforms by themselves. We employ an instrumental variable model to test this argument in a global sample of aid-eligible countries.
\end{abstract}

Keywords Foreign aid · Foreign aid effectiveness $\cdot$ Democracy promotion · Judicial independence $\cdot$ Instrumental variable estimation

\section{Introduction}

Since the 1990s, donor governments have acknowledged the ways in which flawed judicial systems can be obstacles to good governance, democratic accountability, human rights, and transparency (Elster \& Slagstad, 1993; Linz \& Stepan, 1996;

Responsible editor: Axel Dreher

Author contributions to research design and conceptualization: M.A. (30\%), S.D. (40\%), J.W. (30\%); data collection and statistical analysis: MA (10\%), S.D. (10\%), J.W. (80\%); Writing: M.A. (40\%), S.D. (30\%), J.W. (30\%).

\section{Margaret Ariotti \\ mariotti@uga.edu \\ Simone Dietrich \\ Dietrich.simone@gmail.com \\ Joseph Wright \\ Joseph.g.wright@gmail.com}

Extended author information available on the last page of the article 
Maravall \& Przeworski, 2003; Baylies \& Szeftel, 1997; O’Donnell, 1998). However, the role of foreign aid in developing the judiciary has thus far received limited attention, as democracy promotion efforts historically emphasized elections. ${ }^{1}$ As the limits of elections for democratization have become clear in the past decade, donors have turned their attention to efforts to democratize justice systems through targeted judicial reforms. These reforms are have taken many forms, including efforts to "open" judicial selection processes by expanding the number of actors participating in the process of appointing judges to courts, with the goal of altering incentives in such a way as to make future attacks on the democratic process more difficult (Driscoll \& Nelson, 2012, 2015). Underscoring the importance of the rule of law for democratic stability and consolidation, Carothers (1998: 4) thus advocates a shift in attention and resources towards judicial reform.

In addition to its importance for democratization and human rights, the judiciary also matters for economic development. A large literature shows that judicial autonomy, once enforced, is strongly associated with sustained growth because independent courts improve property rights protection and lower transaction costs associated with capital investment (Williamson, 1985; Henisz, 2000; Feld \& Voigt, 2003; Haggard \& Tiede, 2011). ${ }^{2}$ By increasing judicial autonomy, governments increase their credibility vis-'avis investors, which in turn facilitates investment and economic development (Williamson, 1985; North, 1990; Acemoglu et al., 2001; La Porta et al., 2004). Further, judicial autonomy can promote long-term economic growth by providing institutional checks on erratic government policies (Henisz, 2000); by curbing corruption to secure equal treatment and procedural fairness in interactions between public and private actors (Haber et al. 2003); and by expanding the state's institutional capacity (Haggard \& Tiede, 2011).

Although donor governments increasingly hail judicial autonomy as a key element of democratic stability and economic development in aid-recipient countries, to date there is little systematic evidence that evaluates the efficacy of outside efforts to reform judicial systems and, ultimately, promote judicial independence abroad. Our study examines how external democracy promotion efforts influence judicial independence in developing countries. Donor governments across the OECD often treat judicial reform as a guarantor of judicial autonomy, which is seen as important for improving the investment climate. However, incumbent governments have competing incentives when it comes to the pursuit of judicial reforms - while reforms encouraging judicial autonomy can potentially help the incumbent improve development and economic growth (Tate, 1993; Whittington, 2003; Ginsburg, 2003; Hirschl, 2004; Wright, 2009; VonDoepp, 2009; Yadav \& Mukherjee, 2014), reforms can also require leaders to submit to some limits on their behavior. Incumbents may have strategic reasons for pursuing reforms domestically, perhaps so as to better control the specific ways in which their power is circumscribed. Alternatively, they can choose to rely on donors to assist them in this process. Under what conditions does foreign aid help to improve judicial autonomy?

\footnotetext{
${ }^{1}$ For example, Brown (2011) argues that donors working in countries as diverse as Rwanda, Kenya, and Malawi uniformly emphasized multiparty elections. Crawford (2001) notes that joint donor efforts were crucial for leveraging multiparty elections in Africa, where the majority of democratic transitions since 1990 have occurred.

${ }^{2}$ See Haggard and Tiede (2011) for an excellent review of the literature.
} 
We argue that donor efforts to promote judicial independence are most likely to shape the judiciary in places where relinquishing control over the judiciary is particularly pressing for leaders. We argue that this is likely the case in recipient countries with weak state institutions, limited domestic revenue capabilities, and high dependency on foreign aid. In these environments, recipient governments often lack the capacity to design and implement credible domestic reforms that improve judicial autonomy, but they are under pressure to respond to expectations surrounding judicial autonomy so as to attract external revenue sources and support their budgetary needs. We argue that this susceptibility provides a fertile ground for the successful implementation of democracy and governance initiatives that seek to strengthen the independence of the judicial sector. Our empirical results are consistent with our theory: donor efforts to promote judicial reform are more likely to succeed in low-capacity states than in high capacity states.

This study contributes to our understanding of democracy promotion in two ways. First, it advances an argument linking foreign aid to judicial independence through the mechanisms of donor investment in democracy promotion and judicial reforms in particular. ${ }^{3}$ Second, our argument contextualizes the effect of democracy promotion by accounting for important variation in state capacity across aid-receiving countries. Our empirical findings thus contribute to the burgeoning research in foreign aid that examines the conditions under which donors may promote democracy and development abroad.

\section{Democracy aid, state capacity, and the judiciary}

By the mid-1990s, it had become clear that problems in the judiciary were obstacles to improving governance and accountability in many democratizing countries. As donors became aware that the existing focus on free and fair elections was insufficient for democratic consolidation, they turned to the judicial sector for targeted investment. As Lord Paddy Ashdown noted in 2002 shortly after taking up the post of U.N. High Representative for Bosnia and Hercegovina: "[i]n Bosnia, we thought that democracy was the highest priority and we measured it by the number of elections we could organize. In hindsight, we should have put the establishment of rule of law first, for everything else depends on it: a functioning economy, a free and fair political system, the development of civil society, and public confidence in police and courts. We should do well to reflect on this as we formulate our plans for Afghanistan, and, perhaps, Iraq." 4

Today, the rule of law as a concept is universally accepted in the donor community as a critical stepping stone for promoting democratic consolidation and development. The judiciary is a key component of the rule of law, ensuring the application of the law in an independent, fair, and efficient manner, and requiring independence from government intervention. Important guarantees of judicial autonomy include autonomy

\footnotetext{
${ }^{3}$ For research that explores the effect of foreign aid on democracy promotion see e.g. Goldsmith (2001); Dunning

(2004); Finkel, Pérez-Liñán an and Seligson (2007); Scott and Steele (2011); Dietrich and Wright (2015).

${ }^{4}$ Cited in Reenock, Staton and Radean (2010: p.1)
} 
from the government in matters of judicial review, the appointment of judges, and terms of tenure, as well as sufficient resources to ensure the proper operation of the justice system, including the training of judges and access to justice programs (Hanssen, 1999; Domingo, 2000; Russell, 2001; Ginsburg, 2003; Hammergreen, 2007). To strengthen these and other guarantees, donors have spearheaded judicial reform efforts across the world by financing institutional reforms in law, court, and judicial administration, and by investing in the expanding and deepening the legal community in the context of broader democracy and governance programs. Such reforms help to strengthen both de jure and de facto elements of judicial independence.

Though judicial reform is a complex area of intervention-involving a variety of actors in courts, administration, and the legal society - the donor community's modality for promoting institutional reform is very similar across projects. Donors typically provide technical expertise to aid-recipient governments, assist in the implementation of judicial projects, and actively monitor whether institutional change has taken place. For example, Canada's \$17 million investment in Mali's justice development system in 2010 was implemented by the Malian Ministry of Justice (AidData 2016). However, the implementation relied on technical expertise and guidance from international experts who were hosted by the aid-recipient ministry. These experts not only shaped the program design and assisted in the implementation process, they also assumed monitoring and oversight functions on behalf of the donor government to ensure that the project was effectively implemented. While not all reform is an unequivocal boon to judicial autonomy, the common structure shared by many internationally-funded projects and its emphasis on technical capacity-building helps to create a class of professionalized bureaucrats. This cadre has the ability to develop their own professional norms and expertise, and provides qualified professionals with the structure to begin building autonomy. In essence, building technical capacity also creates the possibility for agents to engage in moral hazard, making it more difficult for political leaders to control agents of the judicial apparatus.

While the promotion of judicial autonomy is important for donors, incumbents also have their own incentives to embark on judicial reforms. As a large body of literature has suggested, judicial reform and autonomy are directly linked to economic growth and development via investment: by increasing judicial autonomy, governments increase their credibility vis-'a-vis investors, which in turn facilitates investment and economic development (Williamson, 1985; North, 1990; Acemoglu et al., 2001; La Porta et al., 2004). In addition, judicial autonomy can promote long-term economic growth by providing institutional checks on erratic government policies (Henisz, 2000); by curbing corruption to secure equal treatment and procedural fairness in interactions between public and private actors (Haber et al. 2003); and by expanding the state's institutional capacity (Haggard \& Tiede, 2011). Incumbents may also find strengthening of the judiciary advantageous when public support for particular rights is strong, as allowing limited autonomy to the judiciary may be less costly than widespread repression. Judicial reforms are not without risks for the incumbent, however, as it may be difficult to subsequently reverse reforms that can constrain the incumbent. ${ }^{5}$

\footnotetext{
${ }^{5}$ As a result, judicial reform may be costly for incumbents in the long run, and could lead to instances of 'democracy

by mistake’ (Treisman, 2020).
} 
Incumbents can strategically elect to embark on prescribed reforms in order to limit potential threats to their rule in the future, by arguing that some issues are not legal matters or creating courts with specific jurisdictions to handle politically sensitive cases (Balasubramaniam, 2009; Cheesman, 2011) or even by strategically employing international arbitration in some domains on a case by case basis (Massoud, 2014).

Consistent with Klug (2000) and Landes and Posner (1975), we argue that incumbents in developing countries have incentives to deliver credible policies to investors and donors. To achieve this goal, incumbent governments can either design and implement credible indigenous reform proposals or rely on external assistance. In those instances where the incumbent has the willingness and resources to credibly implement reforms, we expect that they choose whether to do so and act accordingly. Because they have the capacity to engage in credible reforms, the decision to seek external assistance is one of reinforcement, rather than initiative - these regimes have already decided on their desired course of action and a decision to seek external buy-in is secondary. However, in instances where the incumbent lacks resources and credibility to implement reforms, we expect that they will seek external assistance. Whether incumbent governments resort to external assistance in this context, of course, has direct implications for the efficacy of aid in promoting judicial autonomy abroad: we would only expect aid to influence judicial autonomy in environments where indigenous reforms efforts are either not taking place or fall short of achieving credibility. We turn to state capacity as an important prerequisite for the implementation of credible judicial reform: while some aid recipients have the resources and governance systems in place to allow for the design and implementation of reforms, others lack the capacity to do so. ${ }^{6}$ As a concept, state capacity has multiple dimensions that are analytically distinct, yet interrelated and mutually supporting: such dimensions include extractive, coercive, and administrative capacities (Hendrix, 2010; Hanson \& Sigman, Forthcoming). ${ }^{7}$ As our argument centers on the state's ability to design and implement credible judicial reform proposals, we conceptualize state capacity in terms of administrative capacity. Borrowing from Weber (1978), Hanson and Sigman (Forthcoming: p.5) define a capable administration as requiring "technical competence, trusted and professional state agents, monitoring and coordination mechanisms, and effective reach across the state's territory and social groupings." While state capacity does not allow us to distinguish fine-grained variation in a state's commitment to empowering the judiciary,

\footnotetext{
${ }^{6}$ The idea that effective states are built by improving their capacity for governance has a long history in political science. Existing work on state capacity has notably focused on its determinants (Lektzian \& Prins, 2008; Hollenbach et al., 2016; Lake \& Fariss, 2014), and its relationship with political trust and civil conflict (Braithwaite, 2010; Thies, 2010; Hutchison \& Johnson, 2011; Holtermann, 2012; Taydas \& Peksen, 2012). Many of these approaches have focused principally on the coercive force of the state, although state capacity has also been described as a "multi-dimensional concept that encompasses not only the extractive abilities of a state but also economic development and bureaucratic quality" (Sobek, 2010: 267). This attention to other ways of measuring the state's reach has led to an increase in studies operationalizing state capacity in terms of bureaucratic capacity, including the ability extract revenue (Hendrix, 2010; Hanson \& Sigman, Forthcoming; Lee \& Zhang, 2016). As others have shown, strong institutions also increase investments (Knack \& Keefer, 1995; Arbetman-Rabinowitz \& Johnson, 2012; Bearce, 2013).

${ }^{7}$ As Hanson and Sigman (Forthcoming) point out, extractive and coercive capacities are likely conditions for higher levels of administrative capacity, while extractive capacity depends on some level of administrative capacity.
} 
we believe it helps to address a more general sense of the state's ability to allocate resources to its many institutions.

If a state's administrative capacity is relatively strong, incumbent governments can push through judicial reforms to increase judicial autonomy when they desire to do so. If the administrative capacity is low or even absent, judicial reforms, as other types of institutional reforms, are difficult to pursue even when there is a political willingness. We claim that it is in the latter environment where donors can play an important role in promoting judicial autonomy. Through targeted investments in the judiciary branch, donors can strengthen administrative capacities. Specifically, donor-sponsored expert advice assists the government in designing policy and managing its implementation. External monitoring mechanisms are often built into donor-sponsored projects, as is typically the case for investments in democracy and governance promotion. These mechanisms can help recipient administrations reduce corruption and inefficiencies around the implementation of projects (Gibson et al., 2015; Slough \& Fariss, 2021). Finally, incumbent governments in low capacity environments are under particular pressure to respond to demands for judicial autonomy in order to attract external revenue to finance their budgetary needs. This susceptibility provides a fertile ground for the successful implementation of donor investments in judicial reform.

One example of a case where foreign aid has helped to promote judicial autonomy in a relatively low-capacity state is Kenya. For many decades after Kenya's independence, the judiciary functioned as an arm of the executive, used primarily to facilitate and rationalize executive control. Though Kenya's 1964 Independence Constitution included minimal safeguards for the judicial sector, it did not provide an effective framework for the balance of power between the different arms of government. As such, the provisions were inadequate to enable Kenyan courts autonomy from government influence. Kenya's judicial system was thus incapable of effectively checking the excesses of the executive, with anti-establishment court cases routinely ruled in favor of the executive (Murungi, 2005). The legitimacy of courts suffered accordingly. For example, in the aftermath of the 2007 elections, which exhibited strong evidence of electoral fraud by the incumbent, the opposition leaders refused to submit to the jurisdiction of the courts to resolve the election dispute, calling for mass action and rejecting the judiciary's legitimacy as an impartial and independent arbiter. ${ }^{8}$ The lack of trust in judicial institutions contributed to protests and election violence that caused considerable suffering for thousands of people (Abuya, 2009).

Though donors supported and systematically funded projects that were designed to strengthen the rule of law prior to the 2007 Kenyan elections, such activities increased post-2007. Donors have worked with the Ministry of Justice, as well as judicial commissions, to help prepare and implement reform policies that allow for more balanced power among the branches of government, and specifically, a more autonomous judiciary. In 2010 Kenya adopted a new constitution, repealing the 1964 Independence Constitution. This new constitution strengthens the autonomy of the judiciary sector by weakening executive control over the appointment of lower and higher court judges; this is accomplished by assigning shared appointment powers to the legislature. The new constitution also subjects the executive to more stringent

\footnotetext{
${ }^{8}$ The Report of the Commission of Inquiry into Post Election Violence (CIPEV) 2008, Government Printer, Nairobi.
} 
accountability procedures in its relations with the judiciary sector (Kramon \& Posner, 2011).

Donor efforts have continued unabated. One such example includes the work by the multi-donor funded International Development Law Organization (IDLO), an intergovernmental organization devoted to strengthening the Kenyan judiciary with particular focus on court independence in electoral disputes. IDLO's work is funded by many OECD donors, and includes the training of judicial officers and court staff on the new constitution and electoral laws, the promotion of ownership, leadership, and coordination of the electoral dispute resolution mechanism by the judiciary, the delivery of comprehensive, skill-building programs for judges and their support staff, as well as engaging and building the capacity of non-legal partners in the electoral process. ${ }^{9}$

When Kenya's Supreme Court declared the 2017 presidential election as legally void, it dealt a legal blow to incumbent President Kenyatta, who had been initially been declared the victor of the August poll. According to the IDLO, this declaration demonstrates that external support of independence of the judiciary and investing in judicial capacity helps to reinforce democracy. Emphasizing their intention to continue working to strengthen the Kenyan judiciary, IDLO added that "the Kenyan judiciary can effectively and efficiently handle electoral disputes in line with the Constitution."10 The Kenyan case provides an example of the role that donors' capacity-building efforts play in environments where the Ministry of Justice and other relevant agencies had only limited administrative capacity to design and promote reforms.

When recipient countries have sufficient administrative capacity to design and implement reforms, however, we expect foreign aid to be less central to the success of reform initiatives. The evolution of the judiciary in Jordan illustrates the ways in which higher capacity states can engage in reform, with foreign aid playing a less relevant role in the process. Until the late 1990s, Jordan's judiciary was not guaranteed autonomy by the Constitution. ${ }^{11}$ Under King Abdullah II, Jordan's commitment to promote legal reforms has increased, tied explicitly to economic development (Burgis, 2007), and with the suggestion that judicial reforms would "help translate the country's reform plans into facts on the ground, including economic reform and efforts to increase the country's economic competitiveness." ${ }^{.12}$ Specific areas for reform activities included the strengthening of the efficiency of the judicial inspection methodology and developing the institutional capacity of the courts. ${ }^{13}$ Though resistance to reforms by traditional, conservative elites has often stalled the reform agenda, reformers have progressively gained more support for their efforts. ${ }^{14}$

\footnotetext{
${ }^{9}$ IDLO (2017) Avoiding Violence and Enhancing Legitimacy: Judicial Preparedness for Handling Electoral Dis-

putes in Kenya and Beyond. http://www.idlo.int/sites/default/files/pdfs/publications/IDLO-LLB-EDRKenya-Full Report-Final-170,317.pdf. Accessed 1/11/19.

${ }^{10}$ IDLO press release, https://www.idlo.int/strong-dispute-resolution-system-key-2017-kenya-elections, Accessed 1/11/19.

${ }^{11}$ In 2001 laws were passed that strengthened the judiciary vis-a-vis the executive. However, these laws continued

to limit judiciary autonomy insofar as they delegated authority to the Judicial Council for the appointment and dismissal of judges (Burgis, 2007).

12 See http://jordantimes.com/king-supports-judicial-development-strategy. Accessed 3/25/15.

13 See Ibid.

${ }^{14}$ For an overview of Jordanian reform efforts see Muasher (2011).
} 
Reforms to Jordan's judicial system have taken place incrementally over the past two decades, and most were domestic initiatives. In 2005, the King directed the government and a national committee to propose laws that would guarantee judicial autonomy and competence, and in 2012 the first Constitutional Court was sworn in. These actions were followed by a 2013 amendment to judicial law that allows the judiciary to operate without political interference. ${ }^{15}$ In 2016, King Abdullah II established the Royal Committee for Developing the Judiciary and Enhancing the Rule of Law, which produced over 40 specific recommendations to further improve the judiciary system with a view towards strengthening judicial autonomy. ${ }^{16}$ According to the King," the economic and investment environment cannot be improved without an effective and independent judiciary."17

Donors have also contributed to these domestic reform initiatives, supporting the government's actions. For example, the European Union sponsored "Technical Assistance for Institutional Strengthening of the Ministry of Justice," a 1.1 million euro initiative that trained judges, clerks and legal professionals to build modern legal case management systems (AidData 2016). The World Bank has contributed by conducting training programs to upgrade Jordanian judges' capabilities, as well as the skills of prosecutors in Amman. The "Jordan Legal and Judicial Reform Learning Program" focused on analyzing and discussing strategies to secure private property and oversee administrative agencies. ${ }^{18}$ In both cases, donors funded the project after the Jordanian government had already prioritized efforts to reform the judiciary and had demonstrated sufficient administrative capacity to implement the projects effectively. In this environment, the role of donors is more complementary, supporting domestic processes that are already underway, and is thus unlikely to have an independent effect on judicial autonomy. This discussion suggests that a recipient's administrative capacity is an important factor that conditions the efficacy of externally funded judicial reform efforts. Our argument generates testable empirical propositions:

Hypothesis 1a: Donor efforts to promote judicial reform are most likely to have a positive effect on judicial autonomy in countries where state capacity is low (and need for external assistance to design and implement reform is high).

Hypothesis 1b: Donor efforts to promote judicial reform are least likely to have a positive effect on judicial autonomy in countries where state capacity is high (and need for external assistance to design and implement reform is low).

\subsection{Data}

The sample period (1992-2015) corresponds to the first two and a half decades after the end of the Cold War. During this time, donors became more likely to attach political conditions to aid projects and became more selective in distributing aid resources -

\footnotetext{
${ }_{15}$ See http://jordantimes.com/king-supports-judicial-development-strategy Accessed 3/25/15.

${ }^{16}$ See https://www.hrw.org/news/2017/03/14/jordan-strong-move-justice-reform Accessed 1/11/19.

${ }^{17} \mathrm{See}$ http://www.jordantimes.com/news/local/king-holds-judicial-reform-follow-meetings. Accessed 3/14/ 19.

${ }^{18}$ See http://web.worldbank.org/WBSITE/EXTERNAL/WBI/WBIPROGRAMS/PSGLP. Accessed 3/25/15.
} 
both among different countries as well as among different types of recipients within countries (Crawford, 1997, 2001; Dietrich, 2016, 2021; Molenaers et al., 2015). Further, donors continually increased democracy and governance aid during this period, in contrast to the Cold War when donors rarely provided direct democracy assistance. The sample includes all aid eligible countries with democratic or autocratic regimes and populations over 1 million (in 2009). ${ }^{19}$ The main analysis employs eight three-year panels: 1992-1994; 1995-1997; 1998-2000; 2001-2003; 2004-2006; 2007-2009; 2010-2012; and 2013-2015.

Data on judicial independence Our argument generates predictions about the types of states where foreign aid is likely to influence judicial independence. We employ data on de facto judicial independence from Linzer and Staton (2015). This measure focuses on de facto judicial independence as contingent on both autonomous judging as well as judges' ability to make decisions that constrain other actors (Linzer \& Staton, 2015: 225). This measure aggregates information from twelve direct and indirect indicators using a latent variable model. ${ }^{20} \mathrm{We}$ also check the robustness of the main results using data from the Varieties of Democracies project. ${ }^{21}$ Using data on de facto judicial independence helps us to better capture positive and negative changes that occur in judicial practice, even when they are not necessarily reflected in changes directly to the de jure rules and institutions.

Aid data We use democracy aid commitment data from AidData $3.1 .^{22}$ We aggregate aid commitments at the recipient-country-year level. ${ }^{23}$ Our measure of democracy aid subsumes the aid spending that is earmarked for the "Government and Civil Society", per the AidData coding manual. It comprises projects that fall into one or more of the following areas including economic and development policy/making, public sector financial management, legal and judicial development, government administration, strengthening civil society, conflict prevention and resolution, security assistance (including civilian peace-building, reintegration of former combatants into the economy, assistance to control the proliferation of small arms and light weapons. Democracy aid also incorporates distinct delivery modalities. Project examples for democracy and governance aid include those that directly target policy planning in areas such as fiscal and monetary policy, institutional capacity building, and structural reform. DGA also finances tax assessment procedures, legal and judicial development, and constitutional development. Donors use DGA to support government administration by helping finance civil service reform and government infrastructure. In addition to financing governance-related activities, DGA also flows to non-state development actors

\footnotetext{
${ }^{19}$ See Online Appendix A for details on the sample.

${ }^{20}$ See Table A-3 for a list of the manifest indicators. We standardize this variable to have a mean equal to 0 and sample standard deviation of 1 , while noting that $22 \%$ of the variance in judicial independence is withincountry.

${ }^{21}$ See Table D-1. The question employed by the Varieties of Democracies project for this variable is: "When the high court in the judicial system is ruling in cases that are salient to the government, how often would you say that it makes decisions that merely reflect government wishes regardless of its sincere view of the legal record?" (Coppedge et al., 2020).

22 Data downloaded from http://aiddata.org/aiddata-research-releases on 4/29/20.

${ }^{23} \mathrm{We}$ use commitment data rather than disbursements because, especially at the sectoral level, there is substantial missing data on disbursements.
} 
including civil society groups and political parties to support community participation and strengthen political accountability. However, as Dietrich and Wright (2015) show, the bulk of DGA flows to incumbent governments and only a small fraction directly funds non-state actors.

Donors also earmark specific programs to invest in judicial reform in recipient countries. These programs include projects focused on legal training and education, institutional strengthening of legal and judicial systems, as well as constitutional development. ${ }^{24}$ Traditionally, aid in this sector is subsumed under the broader category of democracy aid. For the purposes of modeling exogenous aid flows using an instrumental variables approach (see below), we continue to group judicial aid within the category of democracy aid. We do this because the excluded variable we use in our two- stage analyses does not predict small categories of assistance very well, as is the case for judicial aid programs. Importantly, however, we also employ judicial aid as the explanatory variable, with very similar results to tests that employ democracy and governance assistance. ${ }^{25}$

We leverage disaggregated project-level information to construct measures of aid flows in different sectors. We measure aid as the logged value of the lagged three-year (i.e. panel) average of constant dollar aid per capita. ${ }^{26}$ The time series for smaller categories of aid, such as democracy assistance, show large variation from year to year, so the three-year panel set-up using averages smooths these trends to better capture inflows over the prior period. ${ }^{27}$

The left panel of Fig. 1 plots the global time trend in aid commitments and judicial independence, showing average of per capita aid commitments (log, constant dollar) and the level of de facto judicial independence (scaled). Both data series trend upwards over time, but democracy aid is increasing rapidly over this period whereas judicial independence is rising at a much slower rate. Given the increasing time trends, we model a common time trend with year-effects. The right panel shows democracy aid commitments as well as the share of funds in this sector that are specifically allocated to judicial reform. While democracy aid is increasing over time, judicial aid remains a small fraction of total democracy assistance throughout the post-1990 period.

State capacity data To measure state capacity, we rely on new data from Hanson and Sigman (Forthcoming). They use a measurement model to estimate latent state capacity across the world for over five decades. This approach aggregates information from 21 manifest indicators (i.e. extant data sources) that measure three related subcomponents of state capacity: administrative, coercive, and extractive. Administrative capacity encompasses concepts such as budgetary management, bureaucratic quality, civil service confidence, and the efficient implementation of government decisions, while extractive capacity entails effectiveness of revenue mobilization, taxes as a share of various types of revenue, and statistical capacity (e.g. frequency of census). Finally, coercive capacity captures features of the security (e.g. government monopoly on the use of force, military spending and personnel) and geographic environments (e.g.

\footnotetext{
${ }^{24}$ We classify judicial aid as all projects with sector code 15130 in the AidData Sector Coding Scheme.

25 See Table D-2.

${ }^{26}$ See Figure A-2. We use population data from the Penn World Tables series to calculate an aid per capita measure.

${ }^{27}$ See Online Appendix E for analysis using 4-year panels and annual time series.
} 

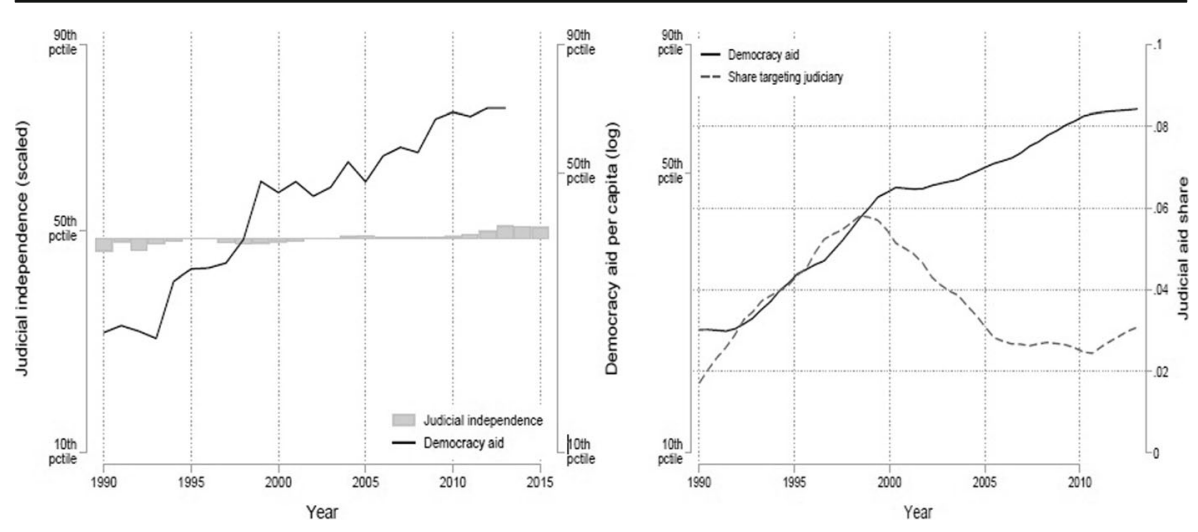

Fig. 1 Foreign aid and judicial independence, 1990-2015

fractal borders and mountainous terrain). In the analysis below, we use the lagged twoyear moving average of state capacity and standardize this variable.

Covariates In the main models reported below, we condition on potential confounders. ${ }^{28}$ Four covariates capture domestic political conditions that correlate with foreign aid and likely influence judicial politics: democracy from Coppedge et al. (2020); an indicator of whether there has been a successful coup in the observation year or the prior year, from Powell (2012); an indicator of an election period from Hyde and Marinov (2012); and regime duration as a measure of how long the current political regime has been in power, from Geddes et al. (2014). More economically developed countries are less likely to receive aid but more likely to have welldeveloped socio-political institutions, including judicial independence. Thus, we might condition on measures such as GDP per capita and economic growth. However, we omit these from our base line specification because GDP per capita and state capacity are highly collinear, and economic growth is plausibly a post-treatment outcome. ${ }^{29} \mathrm{We}$ view this set of covariates as potential confounders and therefore include them in the reported empirical models. To ensure that the model specification with respect to covariate selection is not driving our reported results, we test specifications without control variables as well as specifications with additional time-varying control variables such as GDP per capita, economic growth, population size, media freedom, and constitutional duration. ${ }^{30}$

\subsection{Estimation}

Donors may make aid commitments based on a number of unobservable factors that vary by recipient country. For example, donors who want to foster economic growth may select recipient countries where the institutional environment for promoting investment is strongest; or strategic donors may send more aid to geo-politically

\footnotetext{
${ }^{28}$ See Hayo and Voigt (2007) and Melton and Ginsburg (2014) for a discussion of empirical models of judicial independence.

${ }^{29}$ The Spearman correlation between state capacity and GDP per capita is 0.81 in the estimating sample.

${ }^{30}$ See Table D-5.
} 
important countries. Even if donors, perhaps for ideological reasons, are committed to sending aid to a recipient country with a poor investment climate-allocating more aid to former colonies, for example-donors may still bypass the government in the recipient country and instead fund non-state actors (Dietrich, 2013, 2021).

Further, Western donors have substantially increased democracy aid over the past two decades, leading to a strong time trend in the aid data. To model judicial autonomy, we therefore begin with a linear model and include country and year effects as well as, in some specifications, covariate adjustment:

$$
J I_{i, t}=\propto_{0}+\beta_{1} \operatorname{Aid}_{i, t-1}+\beta_{2} X_{i, t-1}+\eta_{t}+\zeta_{i}+\varepsilon_{i, t}
$$

where $J I_{i, t}$ is judicial independence, $\operatorname{Aid}_{i, t}-{ }_{1}$ is the lagged (one-period) aid, $X_{i, t}-1$ is a set of covariates, $\eta_{t}$ are panel-year effects, $\zeta_{i}$ are recipient country effects, and $\varepsilon_{i, t}$ is the error term. This specification attempts to account for potential confounders, including unobservable country- specific factors, and uses a lagged of the treatment variable to address simultaneity bias and reverse causation. ${ }^{31}$

\subsection{OLS results}

The first column of Table 1 reports the OLS estimates, with no covariates. The estimate for Democracy aid is positive and statistically significant at the 0.05 level, indicating that, on aver- age, democracy aid is positively associated with judicial independence. The second column adds covariates; and the estimate for Democracy aid is small and not significant. To test the main empirical expectation, we add an interaction term to the specifications, in columns (3) and (4): Aid $\times$ Capacity. In these models, the estimate of $\beta_{\text {Aid }}+\beta_{\text {Aid }} \times$ Capacity reflects the marginal effect of aid at varying levels of state capacity. ${ }^{32}$ The estimate for the interaction term in both columns is negative and statistically significant, indicating that the marginal effect of democracy aid declines as state capacity increases. The estimated marginal effect from the model in column (4) for low capacity states (10th percentile of state capacity) is 0.167 and statistically significant, while the marginal effect in high capacity states (90th percentile) is slightly negative $(-0.031)$.

One estimates of a covariate is in the expected direction in column (4): democracy is more judicial independence. Other covariates are not significant, in part because the effect of elections and coups may be short-lived. The estimate for democracy $(0.255)$ is larger than the marginal effect estimate for democracy aid at low capacity levels (0.167), but of the same order of magnitude. This suggests that the substantive effect of democracy aid in low capacity states may slightly smaller than the democracy effect.

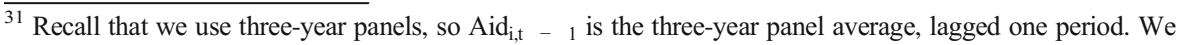
report heteroskedasticity and autocorrelation consistent (HAC) errors.

${ }^{32}$ Analysis in Online Appendix C shows that the data provide sufficient common support for estimating the conditional effects of aid at various values of the conditioning variable (Hainmueller, Mummolo and $\mathrm{Xu}$, 2019). Kernel regression estimates show a declining average value of the average pointwise marginal effect of democracy aid over quintiles of the state capacity variable.
} 


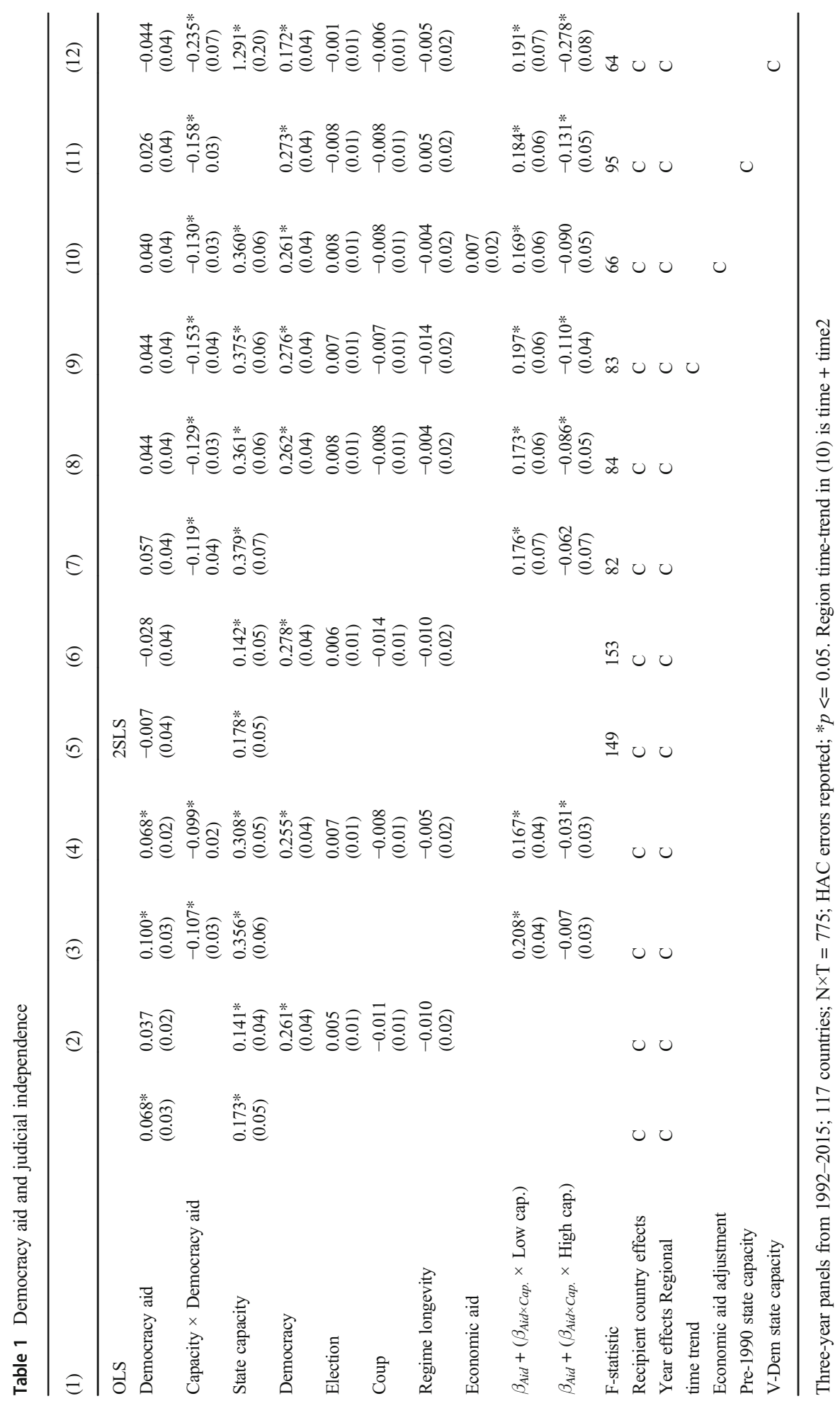




\subsection{Estimate sensitivity with selection on unobservables}

Estimates of the effect of observed aid flows on macro-political outcomes, such as judicial independence, may be biased from selection on unobservable factors. Following the work of Altonji et al. (2005) and Oster (2017), we calculate the bounds of this potential bias in the OLS estimate of $\beta_{\text {DemocracyAid. }}$. This analysis uses information from changes in the point estimates and $\mathrm{R}^{2}$ values derived from a model specification without any 'controls' and from a specification that includes covariates as 'controls', provided the 'control' variables are added to the specification to mitigate bias. Importantly, the test only provides credible bounds for causal interpretation of the estimate of interest if "the omitted variable bias after inclusion of controls is proportional to the coefficient movements and the ratio of the movement in $\mathrm{R}$ squared with inclusion of the observable control to the expected movement in Rsquared with the inclusion of the unobservable controls" (Oster, 2017: 2). While we cannot directly estimate how including unobservables in the specification (in addition to the observed control variables) would influence the estimate of $\beta_{\text {DemocracyAid }}$ and the resulting $\mathrm{R}^{2}$, we can make plausible assumptions about (a) the extent to which the $\mathrm{R}^{2}$ would change when adding unobservables to the specification, and (b) the extent to which the resulting change in the estimate of $\beta_{\text {Democracyaid }}$ is proportional to the change in $\beta_{\text {DemocracyAid }}$ when adding observed covariates (i.e. 'controls') to a baseline specification that only includes the treatment variable of interest.

Three-year panels from 1992 to 2015; 117 countries; $\mathrm{N} \times \mathrm{T}=775$; HAC errors reported; $* \mathrm{p}<=0.05$. Region time-trend in (10) is time + time $^{2}$.

Define $\delta$ as the extent to which unobserved variables are as important as the observed variables in producing a treatment effect that is zero. When $\delta=1$, the unobserved variables are equally important as the observed ones; and $\delta>1$ implies the unobserved variables are more important than the observed ones. Oster (2017: 20) suggests that $\delta=1$ is an appropriate upper bound on $\delta$ because the control variables in the specification should already be selected because researchers believe ex ante these are the most important. Now define the hypothetical $\mathrm{R}^{2}$ of a model with both observed and unobserved covariates as $R_{\max }$. If $R_{\max }=1$, the observed and unobserved covariates explain all the variation in the outcome, with no idiosyncratic component to the outcome data generating process. ${ }^{33}$ In this application, we set $R_{\max }=1$ because including the recipient country- and year- effects in the specification yields an $\mathrm{R}^{2}>$ 0.95 ; thus we allow unobservables to explain the remaining variation in the outcome variable.

We then estimate the treatment effect under the assumption that $R_{\max }=1$ and $\delta=$ 1. In the OLS model reported in column 2 of Table 1 (no interaction term), the estimate

\footnotetext{
${ }^{33}$ The $R_{\max }$ value is undefined because a model with unobserved covariates cannot be estimated. However, we

can make an assumption about $\mathrm{R}_{\max }$ relative to the $\mathrm{R} 2$ value from the regression with observed control variables. If we let $\mathrm{R}^{\sim}$ denote the $\mathrm{R} 2$ from a specification with the treatment and observed controls, then we can define $\mathrm{R}_{\max }=\pi \mathrm{R}^{\sim}$, where $\pi$ is a parameter that varies in the extent to which unobserved covariates increase the R2 - relative to $\mathrm{R}^{\sim}$ - when added to the specification. Thus $\pi=1$ means that all unobserved covariates explain no further variation in

the outcome, while $\pi=2$ means that unobserved covariates explain just as much variation in the outcome as treatment

and the observed variables.
} 
of $\beta_{\text {DemocracyAid }}$ is 0.037 ; and the estimated treatment effect when setting $R_{\max }=1$ and $\delta=1$ is almost the same (0.029). Next, we split the sample into two groups: low capacity and high capacity states. ${ }^{34}$ We then estimate a treatment effect for each subsample under the assumption that $R_{\max }=1$ and $\delta=1$. For low capacity states, the estimate is 0.051 - roughly one-third the size of the estimate $(0.162)$ when setting $\delta=$ 0 (i.e. no unobservables). In high capacity states, the treatment effect when setting $R_{\max }$ $=1$ and $\delta=1$ is -0.029 , which almost identical to the estimate assuming no unobservables $(-0.023)$.

To illustrate how the estimates change under different assumptions, we conduct similar tests but vary $\delta$ from 0 (which implies unobservables have no effect on the outcome) to 1.25 (which implies unobservables are 25\% more important than observed variables included as 'controls'). ${ }^{35}$

Figure 2 shows how the estimated treatment effects for $\beta_{\text {DemocracyAid }}$ for low and high capacity countries change across the range of values for $\delta$. When $\delta=0$, the estimates are similar to those reported in the bottom panel of column 4 in Table 1: 0.167 for $\beta_{\text {Aid }}$ $+\left(\beta_{\text {Aid }} \times\right.$ Cap. $\times$ Low cap. $)$ and -0.031 for $\beta_{\text {Aid }}+\left(\beta_{\text {Aid }} \times\right.$ Cap. $\times$ High cap. $)$. As $\delta$ increases, the estimates of the treatment effect decline but the estimate for aid in low capacity states remains greater than 0 up to the point where $\delta=1.25$, indicating that unobservables would have to explain all the remaining variation in the outcome but also be 25 more important than the observed covariates.

\subsection{Modeling exogenous aid flows}

A second approach to estimating the causal effect of aid on judicial independence addresses concerns that donors may select recipients based on unobserved time-varying factors that contribute to judicial autonomy. The OLS estimate for aid would be biased upwards if, for example, donors give more aid to recipient governments where they expect past improvements in good governance - including judicial independence - to continue apace. Rewarding countries "moving in the right direction" with more funding would result in an upwardly biased estimate for aid. Similarly, if democracy aid intended to help facilitate a fair multiparty election only flows to recipient countries where donors expect improvements in judicial autonomy, the estimate of aid would be upwardly biased. We addressed this concern in the last section by specifying a lower bound for the OLS estimate of $\beta_{\text {DemocracyAid }}$ under selection on unobservables.

However, an OLS estimate might be biased downwards if governance aid disproportionately flows to countries with a poor institutional environment. For example, donors might be more likely to fund democracy promotion activities, such as electoral and judicial administration, in countries with weak courts that are unlikely to develop judicial independence on their own. Donors, for instance, largely funded the 2006 election in the Democratic Republic of Congo (DRC), which in the decade prior to these elections had the seventh-lowest level of judicial autonomy in the world. ${ }^{36}$

\footnotetext{
${ }^{34}$ First we calculate the country average level of state capacity and split the same into two equally sized groups using the median of the average. This means that all time panels for any one country can only be in one sub-sample.

${ }^{35}$ We adjust for the most obvious confouder, Economic aid.

${ }^{36}$ See for International Development (2006) on aid donors' role in funding the 2006 elections.
} 


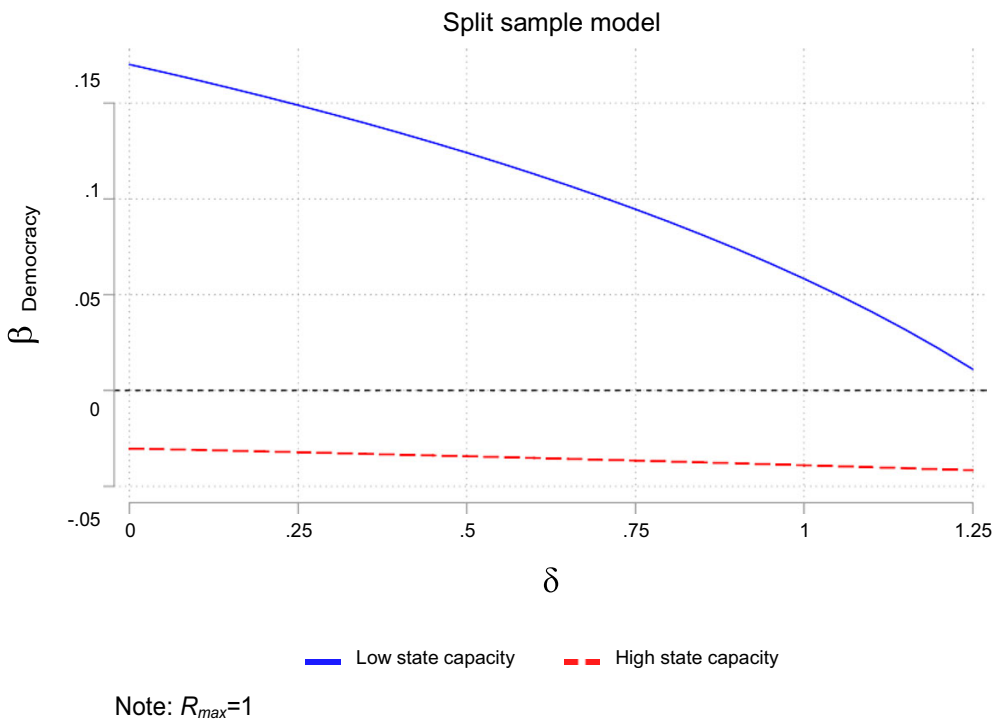

Fig. 2 OLS estimate sensitivity

Identification with an excluded instrument To address endogeneity concerns, we develop an instrument for use in a two-stage model. The time-varying information in the excluded instrument reflects a feature of donor governments that is plausibly exogenous to judicial politics in recipient countries: the number of women in parliament in each donor country-year $\left(W o m P_{j, t}\right)$, from the Inter-Parliamentary Union database. Scholars are in broad agreement that the number of women in parliament in a donor country is associated with increases in the amount of aid (Breuning, 2001; Lu \& Breuning, 2014; Hicks et al., 2016). There is, however, considerable debate regarding whether this is the result of differences in women's policy preferences (the "women's values thesis" described in Breuning (2001)), or whether the relationship between foreign aid and women in parliament is a reflection of greater gender equality in the donor country (Lu \& Breuning, 2014). The cross-sectional information in the instrument is the probability that an aid-eligible country receives aid from a donor in the democracy and governance (including judicial) sector $\left(\bar{P}_{i, j}\right)$. This instrument strategy therefore combines exogenous information from the donor with endogenous crosssectional information on donor selectivity (Nunn \& Qian, 2014; Dreher \& Langlotz, 2020; Dreher et al., 2019). ${ }^{37}$ However, because the outcome model includes recipient country-effects, the endogenous information in $\bar{P}_{i, j}$ is modeled directly, and thus the interactions of the endogenous variable $\left(\bar{P}_{i, j}\right)$ with an exogenous one $\left(W o m P_{j, t}\right)$ can be treated as exogenous (Nunn \& Qian, 2014; Bun \& Harrison, 2018). To construct the excluded instrument, we first estimate a "zero" stage equation ${ }^{38}$ :

$$
\operatorname{Aid}_{i, j, t}=\alpha_{0}+\gamma_{1}\left(\text { WomP }_{j, t} \times \bar{P}_{i, j}\right)+\varepsilon_{i, j, t}
$$

\footnotetext{
${ }^{37} \bar{P}_{i, j}=\frac{\sum_{t=1}^{2 f} P_{i, j, t}}{27}$ where $\mathrm{i}$ indexes recipients, $\mathrm{j}$ indexes donors, and $\mathrm{t}$ indexes year. We calculate aid recipient probability over 27 years from 1987 to 2013 .

${ }^{38}$ Adding recipient country- and year-effects to this equation does not alter the result.
} 
Following Dreher and Langlotz (2020), we then aggregate the predicted values from this equation across all donors, $\mathrm{j}$, for each recipient year $(\mathrm{i}, \mathrm{t})$ to construct the excluded instrument for use in a standard 2SLS model:

$$
\widehat{\operatorname{Aid}}_{i, t}=\sum_{j}\left[\widehat{\gamma}_{1}\left(W_{o m P} P_{i, t} \times \bar{P}_{i, j}\right)+\varepsilon_{i, j, t}\right]
$$

This instrument strategy relies on the differential effect of women in parliament on the level of $\mathrm{D} \& \mathrm{G}$ aid a donor provides to a recipient country with a high relative to a low probability of receiving aid from that particular donor. The identifying assumption is that judicial independence in aid eligible countries with differing probabilities of receiving $D \& G$ aid will not be affected differently by changes in the number of women in parliament in donor countries, once we model recipient country- and yeareffects (Dreher \& Langlotz, 2020; Dreher et al., 2019).

This identification strategy assumes that the excluded instrument, derived from $\bar{P}_{i, j}$ and $\operatorname{Wom}_{j, t}$, is not spuriously correlated with the outcome, judicial independence. Spurious correlation may occur if the time trend in time-varying exogenous information $\left(W o m P_{j, t}\right)$ is correlated with the time trend in the outcome variable $(J I)$ and that correlated time trend varies by the level of the endogenous cross-section component of the instrument, aid regularity or $\bar{P}_{i, j}($ Christian \& Barrett, 2017). Online Appendix B explores this possibility to show that while there is a strong (increasing) time trend in $W_{o m} P_{j, t}$, this time trend is relatively uniformly increase across levels of aid regularity $\left(\bar{P}_{i, j}\right)$. Further, the time trend in the $J I$ outcome variable is nearly flat and consistently flat across levels of aid regularity. This evidence, shown in Fig. B-3, suggests that the instrument is not spuriously correlated with the outcome via an unobserved common time trend that varies systematically by aid regularity. ${ }^{39}$

We further investigate the possibility of a spurious instrument by conducting a randomization placebo test in which we randomly assign aid values within each panel period to other countries in the sample for the same panel period while preserving the true values of aid receipt for all countries that receive no democracy aid in a given period (Christian \& Barrett, 2017: 32). This test preserves the meta-structure of the observed data while creating pseudo-data that should not be predicted very well by the excluded instrument and thus should attenuate estimates of the endogenous variable. Online Appendix Figure B-5 shows the results of 1000 iterations of this test; we find that the distribution of the estimated pseudo-data for the endogenous variable shifts towards zero and that most of the simulationed pseudo data sets yield first stage correlations that are very weak (i.e. very small F-statistics).

This identification strategy also relies on the assumption that the instrument does not influence the outcome via mechanisms other than D \& G aid, including via economic aid. In some specifications, we treat economic aid as a confounder by adjusting for it in the specification. However, even treating economic aid as a confounder cannot rule out the possibility that the instrument exclusion restriction is violated via economic aid. We therefore test whether the instrument predicts democracy aid while adjusting for economic aid (because the two types of aid are correlated) and, conversely, whether the instrument

\footnotetext{
39 The Online Appendix is available the Review of International Organizations' webpage.
} 
predicts economic aid while adjusting for democracy aid. This latter approach reflects the logic of a placebo test: does the excluded instrument predict another causal pathway (economic aid) through which it could shape the outcome (judicial independence)? In specifications that treat democracy aid as the endogenous variable to be predicted by the instrument and that treat economic aid as an observed confounder, we find that the F-statistic for democracy aid exceeds the weak-id critical test value, indicating a strong instrument. Conversely in a placebo test where we treat economic aid as the endogenous variable and democracy aid as an observed confounder, the F-statistic for economic aid falls far below the weak-id test value, indicating a weak instrument. ${ }^{40}$

IV-2SLS specification Because we use a one period lag of the three-year panel average of observed democracy aid, we do the same for the excluded instrument. The set of covariates $\left(\mathbf{X}_{\mathbf{i}, \mathbf{t}}-{ }_{1}\right)$ includes: Democracy, Coup, Regime duration, and Election; while $\eta_{t}$ is a vector of year fixed effect a and $\zeta_{i}$ is a vector of (recipient) country fixed effects. The estimated 2SLS model is the following.

$$
\begin{gathered}
J I_{i, t}=\alpha_{0}+A \widehat{i d_{i, t-1}}+X_{i, t-1}+\eta_{t}+\zeta_{i}+\varepsilon_{i, t}^{1} \\
\operatorname{Aid}_{i, t-1}=\alpha_{0}+\widehat{A i d_{i, t}-1}+X_{i, t}+\eta_{t}+\zeta_{i}+\varepsilon_{i, t}^{2}
\end{gathered}
$$

Because we test a specification that includes an interaction term (Aid $\times$ Capacity) which is partially endogenous, we estimate two "first-stage" equations, one for each endogenous term: Democracy aid $_{i, t}-{ }_{1}$ and Aid $_{i, t}-1 \times$ Capacity $_{i, t}-1$. In this system of equations, we expand the (excluded) instrument set to include $\widehat{A i d_{i, t-1}} \times$ Capacity $_{i, t}-{ }_{1}$. This means we estimate two "first stage" equations, each with two excluded instruments: $A \widehat{i d_{i, t}-1}$ and $A \widehat{i d_{i, t}-1} \times$ Capacity $_{i, t}-{ }_{1}$. For these models we employ an efficient generalized method of moments (GMM) estimator and continue to report HAC errors.

The equations for the endogenous variable(s) are reported in Online Appendix Table B-1, along with a discussion of model diagnostics. In 2SLS specifications with no interaction term, the first-stage Kleibergen-Paap rank Wald F-statistics for the excluded instruments are well above the conventional cut-point of 10 and greater than the Stock-Yogo weak ID test critical values (Stock \& Watson, 2008). In specifications with the interaction term, the F-statistics are smaller, reflecting the increase in variance due to modeling two endogenous variables with two variables in the excluded instrument set, but still exceed the critical value. In sum, we find no evidence of weak instruments in our specifications.

\subsection{SLS results}

Column 5 of Table 1 reports results from the specification with only the endogenous variable, Democracy aid; the 2 SLS estimate is negative but not statistically different

\footnotetext{
${ }^{40}$ These tests adjust for (recipient) country- and year-effects; and we test specifications both with and without additional covariate adjustment. See Figure B-4.
} 
from zero. Column 6 adds potential confounders; the estimate is again negative but statistically insignificant. Because the estimate that adjusts for observed confounders is smaller, a specification that omits confounders may be biased upwards. The 2SLS estimate for Democracy aid in column (6) is negative while the OLS estimate in column (3) is positive, though neither is significant.

The seventh column reports the specification with two endogenous variables, Democracy aid and its interaction with State capacity. The estimate for the interaction term is negative and statistically significant, indicating that state capacity moderates the positive effect of democracy aid. ${ }^{41}$ Column 8 reports results from the interaction specification with covariate adjustment. The estimated marginal effect in low capacity states (10th percentile of state capacity) is 0.17 , while the marginal effect in high capacity states (90th percentile) is -0.08 . These estimates of the marginal effect for low $(0.17)$ and high $(-0.08)$ capacity states are similar in size and direction to the OLS estimates from column 4, 0.17 and -0.03 , respectively. Thus, the 2SLS-IV results for the interaction model are similar to the OLS interaction results.

Column 9-12 present results from important robustness tests. First, we account for possible unobserved time-varying confounding by including a non-linear, geographic region-specific time trend in the specification. The estimates for key variables remain stable. Second, we add economic aid as a potential observed confounder. D \& G assistance and economic aid are positively correlated and we want to ensure that estimates for democracy aid does not capture the effect of economic aid; we therefore test specifications with economic aid as a "blocker", reported in Column 10 of Table 1. Foreign aid, particularly when targeted at governance, can independently influence state capacity. If this occurs, then the measure of state capacity would not be an exogenous regressor. To address this issue, we measure state capacity in the prestudy period as the mean level of state capacity from 1985 to 1989 for each recipient country. Importantly, D \& G aid was minimal prior to the end of the Cold War; therefore, this pre-sample measure of capacity cannot have been shaped by democracy aid. Column 11 reports the specification with an interaction between pre-1990 state capacity and Democracy aid; the constituent term of the interaction (State capacity) is omitted from the specification because it is a cross-sectional measure, the variation in which is captured by the (recipient) country effects. The estimates for key variables remain stable. Finally, column 12 reports a model that uses a measure of state capacity from the Varieties of Democracy project, again with similar results. ${ }^{42}$

Figure 3 shows how the marginal effect of democracy aid - calculated using the 2SLS estimates in column 8 of Table 1 - varies across a range of values for state capacity. For low values of state capacity (less than -0.5 ), the estimated marginal effect is positive and statistically significant at the 0.05 level. ${ }^{43}$ For state capacity values greater than 0.5 , the estimated effect turns negative.

\footnotetext{
${ }^{41}$ Online Appendix Table C-1 shows the results hold when we split the estimating sample at the median value of state capacity, and test the specification, without the interaction term, in low and high state capacity states separately. In each split sample model, the excluded instruments is correlated with the endogenous aid variable. F-statistics are either greater than or the same size as the Stock-Yogo weak-ID critical value.

42 See Online Appendix Table A-5 for details on the the Varieties of Democracy measure of state capacity.

43 State capacity in Egypt in the 1990s, Nicaragua in the late 1990s and early 2000s, and Sri Lanka in the 2000 s is roughly -0.5
} 


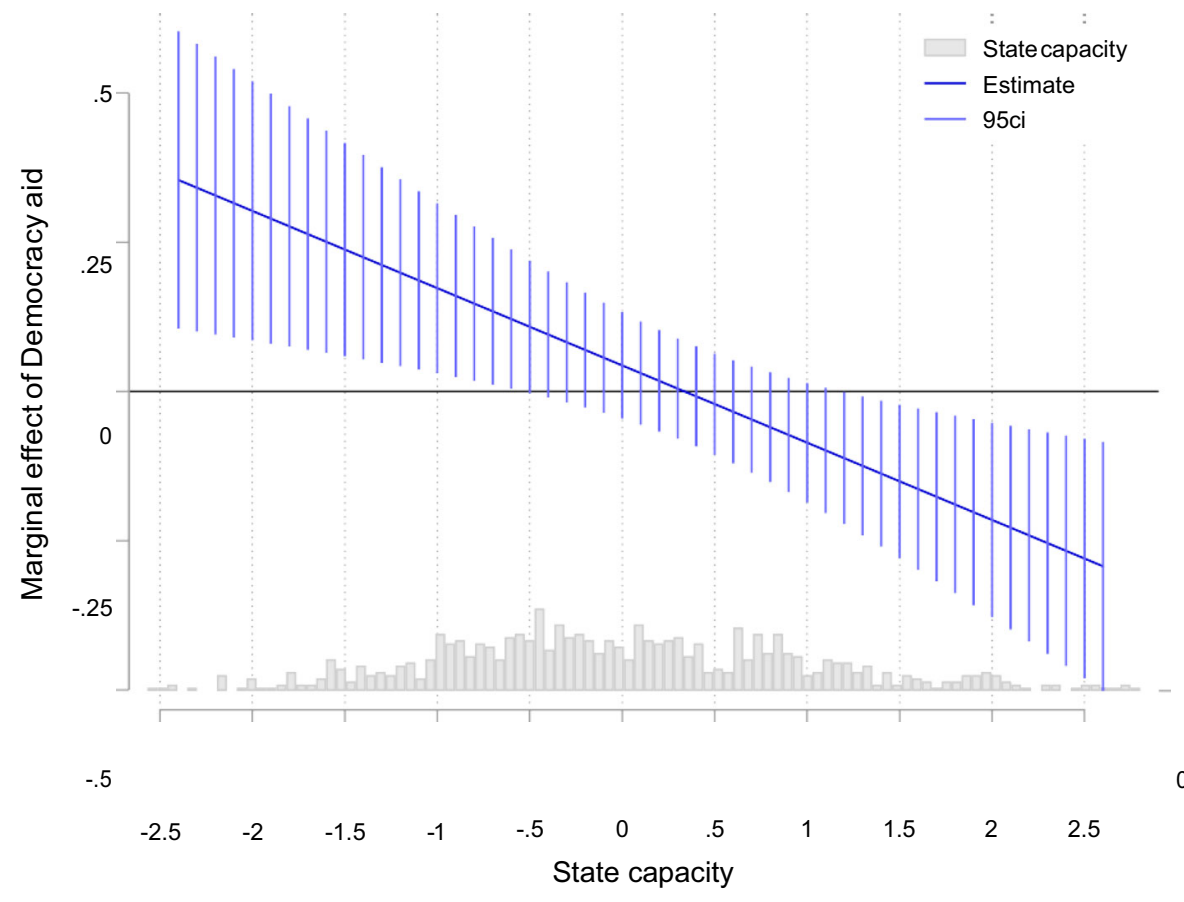

Fig. 3 Aid and judicial independence (1990-2015). 2SLS marginal effects of democracy aid

Robustness tests The Online Appendix reports numerous robustness tests. First, we reproduce the main results using the Varieties of Democracy measure of judicial independence instead of the Linzer-Staton measure (Table D-1); the second models judicial aid instead of democracy aid as the main explanatory variable (Table D-2). We examine split sample and kernel regression tests to examine common support for the interaction model (Online Appendix C) and then model the common time trend with a non-linear time trend or period fixed effects instead of year effects (Table D-3). We also test a series of specifications that add potential confounding variables to the baseline specification (economic aid, GDP per capita, economic growth, population, media freedom, legal system duration) (Figures D-1 and D-2) and specifications that drop confounding variables from the baseline specification (Tables D-4 and D-5). We then provide dynamic estimates that include a lagged dependent variable in the specification (Table D-6). Leave-one-country-out tests (Figure D-3) shows results are not dependent on outlying countries. Finally, we restructure the data into four-year panels and an annual time series (separately) and re-estimate the OLS and 2SLS models reported in the main text (Tables E-1 and E-2), again with stable results.

\section{Conclusion}

The findings suggest several insights into the relationship between foreign aid and judicial autonomy in developing countries. Donor governments can strengthen the 
autonomy of the judicial sector through investments in judicial reforms. We show that increases in democracy and governance aid contribute to strengthening the autonomy of courts in aid-receiving countries. The independent success of donor efforts, however, is limited to environments where the capacity of state institutions - and especially the administrative capacity of states - is relatively low. In environments where the capacity of state institutions is relatively high, we expect incumbent governments to pursue indigenous reform efforts when there is the requisite political willingness to do so. In those instances we expect judicial aid may serve as a complement, but not an independent factor, in strengthening the role of courts.

Our results are consistent with previous research that shows that foreign aid can effectively promote democracy and governance under certain conditions (Dietrich \& Wright, 2015; Gibson et al., 2015; Slough \& Fariss, 2021). In our paper, we expand our knowledge base about these conditions by accounting for important variation in state capacity across aid recipient countries. By focusing only on democracy and governance as well as judicial aid we hold constant the mechanism of aid delivery, which operates largely through the sharing of technical expertise and capacity in institution-building. Our work also resonates with that of Lake (2018) who finds that state fragility can create openings for international human rights NGOs to influence legal processes in ways that strengthen human rights, while the same is not true for countries with strong state institutions.

On its face, our study contrasts with another strand of research that argues that foreign aid contributes to economic growth only under conditions of good policy or institutions (e.g. Burnside and Dollar (2000)); although this study has been shown to lack robustness to different model specifications by a number of follow up studies (Easterly et al., 2004; Rajan \& Subramanian, 2008; Dreher \& Langlotz, 2020). A closer look, however, reveals that the findings of the conditional effectiveness literature had direct implications for the creation of a good governance agenda. The good governance agenda extended across international development actors, insofar as they increasingly devoted their attention to the strengthening of institutions; particularly with a focus on those countries that lacked the capacity to govern themselves (The World Bank, 1997). By focusing only on democracy and governance aid, we show that donor efforts to strengthen institutions may have ultimately paid off, with donors successfully promoting the independence of courts in countries with low levels of state capacity in a post-Cold War context.

Judicial institutions represent an important area for additional research, particularly given the focus on the rule of law in many policy arenas. Future research should examine judicial institutions with respect to the domestic factors that affect judicial autonomy, such as the role played by political competitiveness and the allocation of resources to the judiciary. While finegrained data on budgetary expenditures is difficult to collect on a global basis, a closer examination of the ways in which governments choose to allocate resources across institutions, such as the judiciary, could help to refine the arguments presented here. 
Supplementary Information The online version contains supplementary material available at https://doi.org/ 10.1007/s11558-021-09439-9.

Funding Open Access funding provided by Université de Genève.

Open Access This article is licensed under a Creative Commons Attribution 4.0 International License, which permits use, sharing, adaptation, distribution and reproduction in any medium or format, as long as you give appropriate credit to the original author(s) and the source, provide a link to the Creative Commons licence, and indicate if changes were made. The images or other third party material in this article are included in the article's Creative Commons licence, unless indicated otherwise in a credit line to the material. If material is not included in the article's Creative Commons licence and your intended use is not permitted by statutory regulation or exceeds the permitted use, you will need to obtain permission directly from the copyright holder. To view a copy of this licence, visit http://creativecommons.org/licenses/by/4.0/.

\section{References}

Abuya, E. O. (2009). Consequences of a flawed presidential election. Legal Studies, 29(1), 127-158.

Acemoglu, D., Johnson, S., \& Robinson, J. (2001). The colonial origins of comparative development. American Economic Review, 91, 105-122.

Altonji, J. G., Elder, T. E., \& Taber, C. R. (2005). Selection on observed and un- observed variables: Assessing the effectiveness of Catholic schools. Journal of Political Economy, 113(1), 151-184.

Arbetman-Rabinowitz, M., \& Johnson, K. (2012). Oil ... Path to Prosperity or Poverty? In The Performance of Nations, ed. Jacek Kugler and Ronald L. Tammen. Rowman and Littlefield Publishers chapter 6, pp. 138159.

Balasubramaniam, R. R. (2009). Judicial politics in authoritarian regimes. University of Toronoto Law Journal, 59(3), 405-415.

Baylies, C., \& Szeftel, M. (1997). The 1996 Zambian elections: Still awaiting democratic consolidation. Review of African Political Economy, 24(71), 113-128.

Bearce, D. (2013). Reconsidering the effect of political regime type on foreign aid effectiveness. International Interactions, 3, 416-424.

Braithwaite, A. (2010). Resisting infection: How state capacity conditions conflict contagion. Journal of Peace Research, 47(3), 311-319.

Breuning, M. (2001). Women's representation and development assistance: A cross-national study. Women \& Politics, 23(3), 35-55.

Brown, S. (2011). Well, what can you expect? Donor officials' apologetics for hybrid regimes in Africa. Democratization, 18(2), 512-534.

Bun, M., \& Harrison, T.D. (2018). OLS and IV estimation of regression models including endogenous interaction terms. Econometric Reviews pp. 1-14.

Burgis, M. (2007). Judicial reform and the possibility of democratic rule in Jordan: A policy perspective on judicial Independence. Arab Law Quarterly, 21, 135-169.

Burnside, C., \& Dollar, D. (2000). Aid, policies, and growth. The American Economic Review, 90(4), 847868.

Carothers, T. (1998). The rule of law revival. Foreign Affairs, 77(2), 95-106.

Cheesman, N. (2011). How an authoritarian regime in Burma used special courts to defeat judicial Independence. Law and Society Review, 45(4), 801-830.

Christian, P., \& Barrett, C.B. (2017). Revisiting the effect of food aid on conflict: A methodological caution. The World Bank Policy Research Working Paper (8171).

Coppedge, Michael, John Gerring, Carl Henrik Knutsen, Staffan I. Lindberg,Jan Teorell, David Altman, Michael Bernhard, M. Steven Fish, Adam Glynn, Allen Hicken, Anna Lührmann, Kyle L. Marquardt, Kelly McMann, Pamela Paxton, Daniel Pemstein, Brigitte Seim, Rachel Sigman, Svend-Erik Skaaning, Jeffrey Staton, Agnes Cornell, Lisa Gastaldi, Haakon Gjer-løw, Valeriya Mechkova, Johannes von Römer, Aksel Sundtröm, Eitan Tzelgov, Luca Uberti, Yi-tingWang, Tore Wig, and Daniel Ziblatt. (2020). V-Dem [Country-Year/Country-Date] Dataset v10. Varieties of Democracy (V-Dem) Project. 
Crawford, G. (1997). Foreign aid and political conditionality: Issues of effectiveness and consistency. Democratization, 4(3), 69-108.

Crawford, G. (2001). Foreign aid and political reform: A comparative analysis of democracy assistance and political conditionality. Palgrave Macmillan.

Dietrich, S. (2013). Bypass or engage? Explaining donor delivery tactics in foreign aid allocation. International Studies Quarterly, 57(4), 12-27.

Dietrich, S. (2016). Donor political economies and the pursuit of foreign aid effectiveness. International Organization, 70(1), 65-102.

Dietrich, S. (2021). States, markets, and foreign aid. Cambridge University Press.

Dietrich, S., \& Wright, J. (2015). Foreign aid allocation tactics and democratic change in Africa. Journal of Politics, 77(1), 216-234.

Domingo, P. (2000). Judicial Independence: The politics of the supreme court in Mexico. Journal of Latin American Studies, 32(3), 705-735.

Dreher, A., \& Langlotz, S. (2020). Aid and growth: New evidence using an excludable instrument. Canadian Journal of Economics/Revue canadienne d 'économique, 53, 1162-1198.

Dreher, A., Fuchs, A., \& Langlotz, S. (2019). The effects of foreign aid on refugee flows. European Economic Review, 112, 127-147.

Driscoll, A., \& Nelson, M. J. (2012). The 2011 judicial elections in Bolivia. Electoral Studies, 31(3), 628-632.

Driscoll, A., \& Nelson, M. J. (2015). Judicial selection and the democratization of justice: Lessons from the bolivian judicial elections. Journal of Law and Courts, 3(1), 115-148.

Easterly, W., Levine, R., \& Roodman, D. (2004). Aid, policies, and growth: Comment. The American Economic Review, 94(3), 774-780.

Elster, J., \& Slagstad, R. (1993). Constitutionalism and democracy. Cambridge University Press.

Feld, L., \& Voigt, S. (2003). The economics of convention. European Journal of Political Economy, 19(3), $105-122$.

Geddes, B., Wright, J., \& Frantz, E. (2014). Autocratic breakdown and regime transitions: A new data set. Perspectives on Politics, 12(2), 313-331.

Gibson, C. C., Hoffman, B. D., \& Jablonski, R. S. (2015). Did aid promote democracy in Africa? The role of technical assistance in Africa's transition. World Development, 68, 323-335.

Ginsburg, T. (2003). Judicial review in new democracies: Constitutional courts in Asian cases. Cambridge University Press.

Goldsmith, A. A. (2001). Foreign aid and statehood in Africa. International Organization, 55, 123-148.

Haber, S., Razo, A., \& Maurer, N. (2003). The Politics of Property Rights: Political Instability, Credible Commitments, and Economic Growth in Mexico, (pp. 1876-1929) Cambridge University Press.

Haggard, S., \& Tiede, L. (2011). The rule of law and economic growth: Where are we? World Development, 39(5), 673-685.

Hammergreen, L. (2007). Envisioning reform: Improving judicial performance in Latin-America. Pennsylvania State University Press.

Hanson, J. K., \& Sigman, R. (Forthcoming). Leviathan's latent dimensions: Measuring state capacity for comparative political research. Journal of Politics.

Hanssen, A. (1999). Appointed courts, elected courts, and public utility regulation: Judicial Independence and the energy crisis. Business and Politics, 1(2), 179-201.

Hayo, B., \& Voigt, S. (2007). Explaining de facto Judicial Independence. International Review of Law and Economics, 27(3), 269-290.

Hendrix, C. S. (2010). Measuring state capacity: Theoretical and empirical implications for the study of civil conflict. Journal of Peace Research, 47(3), 273-285.

Henisz, W. (2000). The institutional environment for economic growth. Economics and Politics, 12(1), 1-31.

Hicks, D. L., Hicks, J. H., \& Maldonado, B. (2016). Women as policymakers and donors: Female legislators and foreign aid. European Journal of Political Economy, 41, 46-60.

Hirschl, R. (2004). Towards Juristocracy: The origins and consequences of the new constitutionalism. Harvard University Press.

Hollenbach, F., Wibbels, E., \& Ward, M. (2016). State building and the geography of governance: Evidence from satellites. Unpublished manuscript.

Holtermann, H. (2012). Explaining the development-civil war relationship. Conflict Management and Peace Science, 29(1), 56-78.

Hutchison, M. L., \& Johnson, K. (2011). Capacity to trust? Institutional capacity, conflict, and political trust in Africa, 2000-2005. Journal of Peace Research, 48, 737-752.

Hyde, S. D., \& Marinov, N. (2012). Which elections can be lost? Political Analysis, 20(2), 191-2010. 
Klug, H. (2000). Constituting democracy: Law, globalism and South Africa's political reconstruction. Cambridge University Press.

Knack, S., \& Keefer, P. (1995). Institutions and economic performance: Cross-country tests using alternative institutional measures. Economics and Politics, 7(3), 207-227.

Kramon, E., \& Posner, D. N. (2011). Kenya's new constitution. Journal of Democracy, 22(2), 89-103.

La Porta, R., Silanes, F. L.-d., \& Pop-Eleches, C. (2004). Judicial checks and balances. The Journal of Political Economy, 112, 445-4701.

Lake, M. (2018). Strong NGOs and weak states: Pursuing gender justice in the Democratic Republic of Congo and South Africa. Cambridge University Press.

Lake, D. A., \& Fariss, C. J. (2014). Why international trusteeship fails: The politics of external authority in areas of limited statehood. Governance: An International Journal of Policy and Administration, 27(4), 569-587.

Landes, W. M., \& Posner, R. A. (1975). The independent judiciary in an interest-group perspective. The Journal of Law and Economics, 18(3), 875-901.

Lee, M. M., \& Zhang, N. (2016). Legibility and the informational foundations of state capacity. Journal of Politics, 79(1), 118-132.

Lektzian, D., \& Prins, B. C. (2008). Taming the leviathan: Examining the impact of external threat on state capacity. Journal of Peace Research, 45(5), 613-631.

Linz, J. J., \& Stepan, A. (1996). Problems of democratic transition and consolidation: Southern Europe, South America, and post-communist Europe. The Johns Hopkins University.

Linzer, D. A., \& Staton, J. K. (2015). A Global Measure of Judicial Independence, 1948-2012. Journal of Law and Courts, 3(2), 223-256.

Lu, K., \& Breuning, M. (2014). Gender and generosity: Does women's representation affect development cooperation? Politics, Groups, and Identities, 2(3), 313-330.

Maravall, J. M., \& Przeworski, A. (2003). Courts and power in Latin America and Africa. Cambridge University Press.

Massoud, M. F. (2014). International arbitration and judicial politics in authoritarian states. Law and Social Inquiry, 39(1), 1-30.

Melton, J., \& Ginsburg, T. (2014). Does De jure judicial Independence really matter? A reevaluation of explanations for judicial Independence. Journal of Law and Courts, 2(2), 187-217.

Molenaers, N., Dellepiane, S., \& Faust, J. (2015). Political conditionality and foreign aid. World Development, $75,2-12$.

Muasher, M. (2011). A decade of struggling reform efforts in Jordan: The resilience of the Rentier system. Carnegie Endowment for International Peace.

Murungi, K. (2005). Relationship between the three Branches of Government. In Report of the Relationship between the Three Arms of Government. London: Commonwealth Secretariat.

North, D. (1990). Institutions, institutional change and economic performance. Cambridge University Press.

Nunn, N., \& Qian, N. (2014). US food aid and civil conflict. American Economic Review, 104(6), 1630-1666.

O’Donnell, G. (1998). Challenges and opportunities of judicial Independence research. Journal of Democracy, 9(3), 112-126.

Oster, E. (2017). Unobservable selection and coefficient stability: Theory and evidence. Journal of Business \& Economic Statistics, 1-18.

Powell, J. M. (2012). Determinants of the attempting and outcome of coups d'etat. Journal of Conflict Resolution, 56(6), 1017-1040.

Rajan, R. G., \& Subramanian, A. (2008). Aid and growth: What does the cross- country evidence really show? The Review of Economics and Statistics, 90(4), 643-665.

Reenock, C., Staton, J.K., \& Radean, M. (2010). Judicial Independence and the democratic order. Unpublished manuscript.

Russell, P. H. (2001). Towards a general theory of judicial independence. In D. M. O'Brien \& P. H. Russell (Eds.), Judicial independence in the age of democracy: Critical perspectives from around the world (pp. 75-104). University of Virginia Press.

Scott, J. M., \& Steele, C. A. (2011). Sponsoring democracy: The United States and democracy aid to the developing world, 1988-2001. International Studies Quarterly, 55(1), 46-69.

Slough, T., \& Fariss, C. J. (2021). Misgovernance and human rights: The case of illegal detention without intent. American Journal of Political Science, 65(1), 148-165.

Sobek, D. (2010). Masters of their domains: The role of state capacity in civil wars. Journal of Peace Research, 47(3), 267-271.

Stock, J. H., \& Watson, M. W. (2008). Heteroskedasticity-robust standard errors for fixed effects panel data regression. Econometrica, 76(1), 155-174. 
Tate, C. N. (1993). Courts and crisis regimes: A theory sketch with Asian case studies. Political Research Quarterly, 46(2), 311-333.

Taydas, Z., \& Peksen, D. (2012). Can states buy peace? Social welfare spending and civil conflicts. Journal of Peace Research, 49(2), 273-287.

The World Bank. (1997). The state in a changing world: World development report 1997. Oxford University Press.

Thies, C. G. (2010). Of rulers, rebels, and revenue: State capacity, civil war onset, and primary commodities. Journal of Peace Research, 47(3), 321-332.

Treisman, D. (2020). Democracy by mistake: How the errors of autocrats trigger transitions to freer government. American Political Science Review, 114(3), 792-810.

Tierney, M. J., Nielson, D. L., Hawkins. D. G., Roberts, J. T., Findley, M. G., Powers, R. M., Parks B., Wilson, S. E., \& Hicks, R. L. (2011). More Dollars than Sense: Refining Our Knowledge of Development Finance Using AidData. World Development 39 (11): 1891-1906. Updated in: AidData. 2017. AidDataCore_ResearchRelease_Level1_v3.1 Research Releases dataset. AidData. https:/aiddata.org/ datasets.

VonDoepp, P. (2009). Judicial politics in new democracies: Cases from southern Africa. Lynne Rienner.

Weber, M. (1978). Economy and society: An outline of interpretive sociology. University of California Press.

Whittington, K. E. (2003). Legislative sanctions and the strategic environment of judicial review. International Journal of Constitutional Law, 1(3), 446-474.

Williamson, O. (1985). The economic institutions of capitalism: Firms, markets, relational contracting. Free Press.

Wright, J. (2009). How foreign aid can Foster democratization in authoritarian regimes. American Journal of Political Science, 53(3), 552-571.

Yadav, V., \& Mukherjee, B. (2014). Democracy, electoral systems, and judicial empowerment in developing countries. New Comparative Politics. University of Michigan Press.

Publisher's note Springer Nature remains neutral with regard to jurisdictional claims in published maps and institutional affiliations.

\section{Affiliations}

\section{Margaret Ariotti ${ }^{1} \cdot$ Simone Dietrich ${ }^{2} \cdot$ Joseph Wright ${ }^{3}$}

1 University of Georgia, Athens, GA, USA

2 University of Geneva, Geneva, Switzerland

3 Pennsylvania State University, State College, PA, USA 